\title{
LITHOSPHERE STRUCTURE AND THERMAL REGIME OF THE UPPER MANTLE BENEATH THE BAIKAL REGION: EVIDENCE FROM DEEP-SEATED XENOLITHS
}

\author{
Konstantin Litasov ${ }^{1}$, Yury Litasov ${ }^{2}$, Vladimir Malkovets ${ }^{2}$, Hiromitsu Taniguchi ${ }^{3}$ \\ ${ }^{1}$ Inst. Mineral. Petrol. Econ. Geol., Tohoku University, Sendai, Japan; ${ }^{2}$ United Inst. Geol. Geophys. Mineral. SB RAS, \\ Novosibirsk, Russia; ${ }^{3}$ Center for Northeast Asian Studies, Tohoku University, Sendai, Japan
}

\section{INTRODUCTION}

The geological and geochemical evolution of south margin of Siberian Craton, characterized by widespread Cenozoic volcanism, is generally considered to be the result of the development of the Baikal rift structure and ascending of mantle plume or several mantle plumes from the depths. Late Cenozoic volcanics often contain deep-seated xenoliths of mantle or crustal origin. Precision studies of limited collections of mantle xenoliths from Bartoy, Hamar-Daban, and Vitim volcanic fields were given recently by Ionov et al. (1992; 1993; 1995).

We review here lithosphere structure and thermal regime of the upper mantle based on a detailed account of the distribution, structural and textural relations, and chemical characteristics of the mantle xenoliths from the Baikal region. The Vitim volcanic field holds major role, because Vitim xenoliths are widely studied. They include widest variety of xenolith types, and contain garnet-bearing peridotite xenoliths in basaltic rock of at least two eruption episodes (Late Miocene and PlioPleistocene). Other described units cover in geographical sequence, from west to east, Tuva (Azas volcanic field), East Sayan (Oka volcanic field), Tunka and Hamar-Daban volcanic areas, including unique locality of Bartoy River, Burkal area, and Udokan volcanic field (Fig.1). Xenoliths in the alkaline basalt of the Shavaryn-Tsaram volcanic center of the Taryat depression in Central Mongolia (e.g. Ionov et al., 1998) are considered for comparison. Total set of presented materials was included to the recent review by Litasov and Taniguchi (2002).

\section{GEOLOGICAL BACKGROUND}

\section{Geological Outhine}

The evolution of the Baikal rift zone and adjacent areas occurred in several major stages. Pre-rift geodynamic evolution include (1) formation of the Siberian craton in the Archaean-Early Proterozoic, (2) development the
Palaeo-Asian ocean along southern margin of the Siberian Craton in the Late-Proterozoic - EarlyPalaeozoic, (3) evolution of Palaeo-Mongol-Okhotsk fold belt in the Early-Middle Palaeozoic and progressive closure of the Mongol-Okhotsk oceanic gulf in the Late Palaeozoic - Mesozoic (Delvaux et al., 1995).

The collision of India and Eurasia near $60 \mathrm{Ma}$ ago and following pressure of the India northwards initiated many Cenozoic tectonic processes in the Central Asia. A large part of the Asian plate was affected by compressive stress, generated by this collision, but also constrained by the Pacific/Asia subduction (Zonenshain and Savostin, 1981). According to Logatchev and Zorin (1992), Windley and Allen (1993) and many others, however, the development of the Baikal rift and adjacent region in Mongolia is mainly related to the intrusion of a large asthenospheric diapir. Kiselev and Popov (1992) consider the tectonic evolution of Baikal and North Mongolia as a combination of these two processes, the India-Asia convergence and uplift of hot mantle plume.

Seismic data, regional gravity anomalies, and magnetotelluric measurements were used to show that the mantle, especially below main rift depression of the Baikal Lake, has an anomalously low velocity (Zorin et al., 1989), decreasing sharply on the north side from $150 \mathrm{~km}$ in the Siberian craton to about $50 \mathrm{~km}$ under Baikal. This zone is extended from the Hangai Dome in the South to the Udokan range in the North.

\section{MAGMATISM}

The territory of Siberian craton and its southern boundary were repeatedly involved to the intensive magmatic reworking. Examples of the results of this activity were formation of the largest Angara-Vitim batholite in Ordovician-Silurian, enormous flood basalt eruptions in the Devonian (Vilyuy basin) and in the Permian-Triassic (Tunguska basin), the Mesozoic Aldan alkaline province. The evolution of these different provinces, including also the adjacent area of 


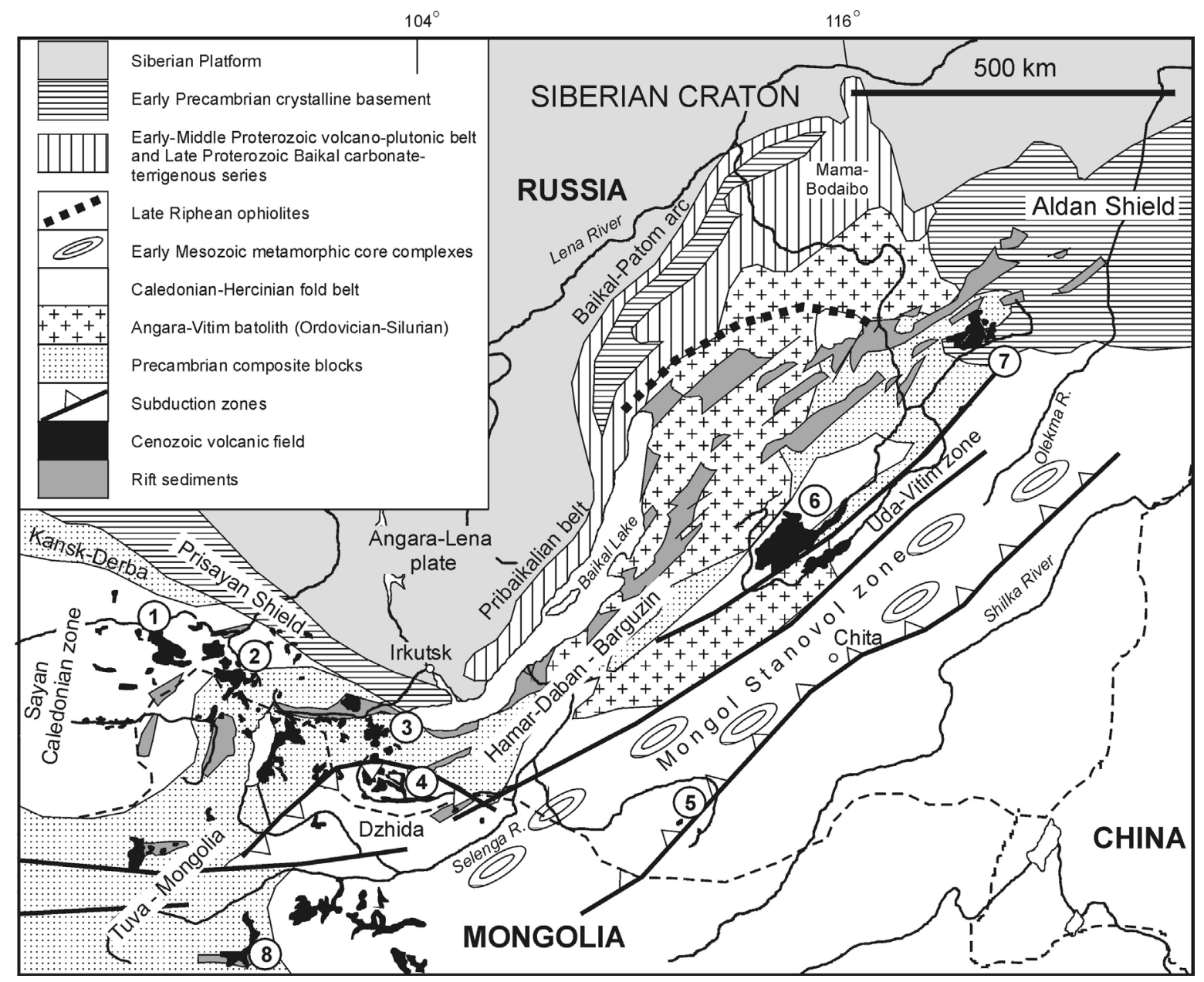

Figure 1: Tectonic setting of the Pre-Mesozoic basement and distribution of Cenozoic alkaline basalts in the Baikal region (Delvaux et al., 1995; Litasov and Taniguchi, 2002). Important volcanic fields and areas: 1, Azas (East Tuva); 2, Oka (East Sayan); 3, Hamar-Daban; 4, Bartoy; 5, Burkal (Khentey); 6, Vitim; 7, Udokan; 8, Taryat (Hangai).

Mongolia with huge Mesozoic magmatism, is thought to be controlled by individual mantle plumes, whose activities, in turn, were controlled by the long-lived North Asia superplume.

After Late Cretaceous stabilization volcanic activity started near $70 \mathrm{Ma}$ ago in the Tunka-Eravna group of basins (Rasskazov, 1994). Several stages of Cenozoic volcanic activity can be distinguished using age determinations: (1) Early Paleogene (65-55 Ma); (2) Late Oligocene (30-20 Ma); (3) Middle-Late Miocene (15-5 Ma); and (4) Plio-Pleistocene (3.5-0 Ma). Almost all volcanic fields have several eruption stages and have the Pliocene-Quaternary volcanic cones and valley lava flows. Cenozoic volcanic fields may be axial and off axial in relation to the central basin of the rift system (Fig.1). Off axial field include Vitim, Bartoy and Burkal. Hangai localities (Taryat) also located outside of main rift structures but correspond to the region with low velocity zone lying near $50 \mathrm{~km}$ depths.

\section{MANTLE GEOTHERMS}

Fig.2 shows the comparison of geotherms constrained by Gt-bearing xenoliths from different suites of the Baikal rift zone and adjacent areas (see Litasov and Taniguchi, 2002). The geotherm for the Gt and Gt-Sp peridotite in Plio-Pleistocene basanites of the Vitim volcanic field is $50-100^{\circ} \mathrm{C}$ hotter than that for peridotite from Miocene picrobasalts. The former is slightly lower than the reference SEA-geotherm, but has different slope. Temperature and pressure estimates of Group II megacrystalline pyroxenites from Miocene picrobasalt indicating input of magmatic heat and disequilibrium with Gt and Sp peridotite country rocks (Litasov et al., 


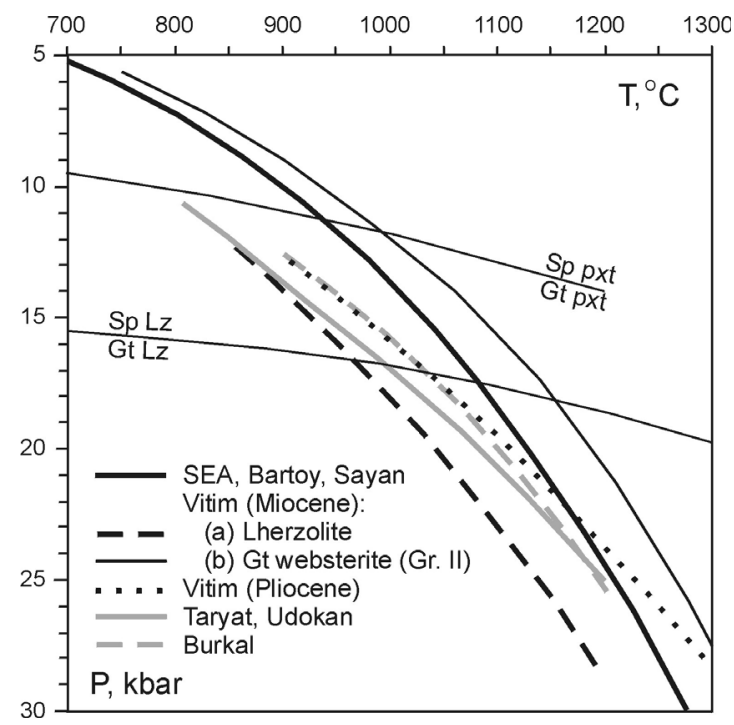

Figure 2: Comparison of different geotherms constrained by mantle xenoliths from Baikal locations (calculated using thermometers of Wells, 1977 and Brey and Kohler, 1990, and barometer of Nickel and Green, 1985; data source: Litasov and Taniguchi, 2002). The reference southeastern Australia geotherm (SEA: O'Reilly and Griffin, 1985) is shown for comparison. Transition boundaries: Sp Lz / Gt Lz, between fertile Sp- and Gt-lherzolite with $\mathrm{Mg} \#=0.90$ and $\mathrm{Cr} \#_{\mathrm{Sp}}=0.10$ (O’Neill, 1981); Sp Pxt / Gt Pxt, between Gt- and Spplagioclase pyroxenites in CMAS system (Herzberg, 1978).

2000a). T-P estimations for Gt and Sp lherzolites from Pliocene-Pleistocene basalts of South Baikal show essential heating of lithosphere, evidenced from Bartoy and Sayan geotherms and similarity of temperatures for spinel peridotites in these localities and Hamar-Daban area. Moreover, we should expect even stronger heating in Miocene time, because of the major volcanic eruptions 10-15 Ma years ago and detected highest temperatures for Dry River xenoliths from $18 \mathrm{Ma}$ basalts (Ashchepkov, 1991).

T-P estimations for Udokan xenoliths suggest possible similarities between thermal profile beneath the Udokan with those of Taryat region in the Central Mongolia (Ionov et al., 1998). Both volcanic areas are located in the peripheral part of zone with anomalous mantle and thin lithosphere (Fig.1).

\section{LITHOSPHERE MODELING}

\section{VITIM, MIOCENE}

The abundance and variety of pyroxenite and metasomatized peridotite xenoliths found in the Miocene picrobasalts indicate the presence of a complexly enriched mantle beneath the Vitim volcanic field. Two major channel networks in the fertile Gt/Spperisotite matrix are present: (1) megacrystic bodies and (2) thin hydrous veins. Megacryst assemblages have not been found in contact with wall peridotite and seem to compose large pegmatoid dykes or other bodies over a wide pressure-temperature range from about 35 kbar at $1300-1380^{\circ} \mathrm{C}$ to $11 \mathrm{kbar}$ at $990^{\circ} \mathrm{C}$. The lack of textural equilibrium and the preservation of HFSE enrichment in metasomatized nodules indicate that their formation was followed closely by the entrainment of the xenoliths in the host magma. We believe it is probable that the two later melt types are related genetically to the development of the Baikal Rift. Firstgeneration pyroxenites are formed by the infiltration of asthenospheric melt into the lower lithosphere, and these veins are remelted shortly afterwards by the upward and outward movement of the asthenospherelithosphere boundary and recrystallize to form a second vein generation at a slightly higher level.

\section{Vitim, Plocene}

The xenoliths suite in Miocene picrobasalts and in Pliocene basanites are drastically differed. Hydrous pyroxenites, observed among the picrobasalt xenoliths, are extremely rare among the basanite xenoliths. Thus, we conclude magma channels were spatially separated from those formed in the Miocene. Unique wellstratified peridotite series in the Pliocene basanites of the Dzhilinda River include: (1) high-T Gt and Sp lherzolites, (2) low-T spinel lherzolites and harzburgites, (3) low-T Ti-rich spinel lherzolites (Litasov et al., 2000b). Protogranular peridotites of the Series 1 represent primitive to moderately depleted mantle from the depths of $60-80 \mathrm{~km}$ at $\mathrm{T}=1000-1150^{\circ} \mathrm{C}$. Peridotites of the Series 2 correspond to the depths $40-50 \mathrm{~km}$ at $\mathrm{T}=800-950^{\circ} \mathrm{C}$. Ti-rich peridotites, enriched in pyroxenes and spinel, were newly detected. They have a mosaic equigranular texture and are suggested to be a rare type of melt/mantle interaction (Cpx has MORBlike REE patterns and extremely enriched in HFSE). Testimations within $780-850^{\circ} \mathrm{C}$ projected to a geotherm correspond to the uppermost mantle section.

\section{SOUTH BAIKAL}

Mantle xenoliths from volcanic fields along axial part of the Baikal rift zone generally represent the uppermost mantle domain with abundant depleted nodules of harzburgites and absence of intensive hydrous metasomatism. Tunka and Hamar-Daban areas (especially Dry River outcrop) are located directly on the axis of rift system in the Southern part of Baikal rift zone. Oka volcanic field and Bartoy volcanic fields are 
( a ) Vitim (Miocene)

(b) Udokan (Miocene)
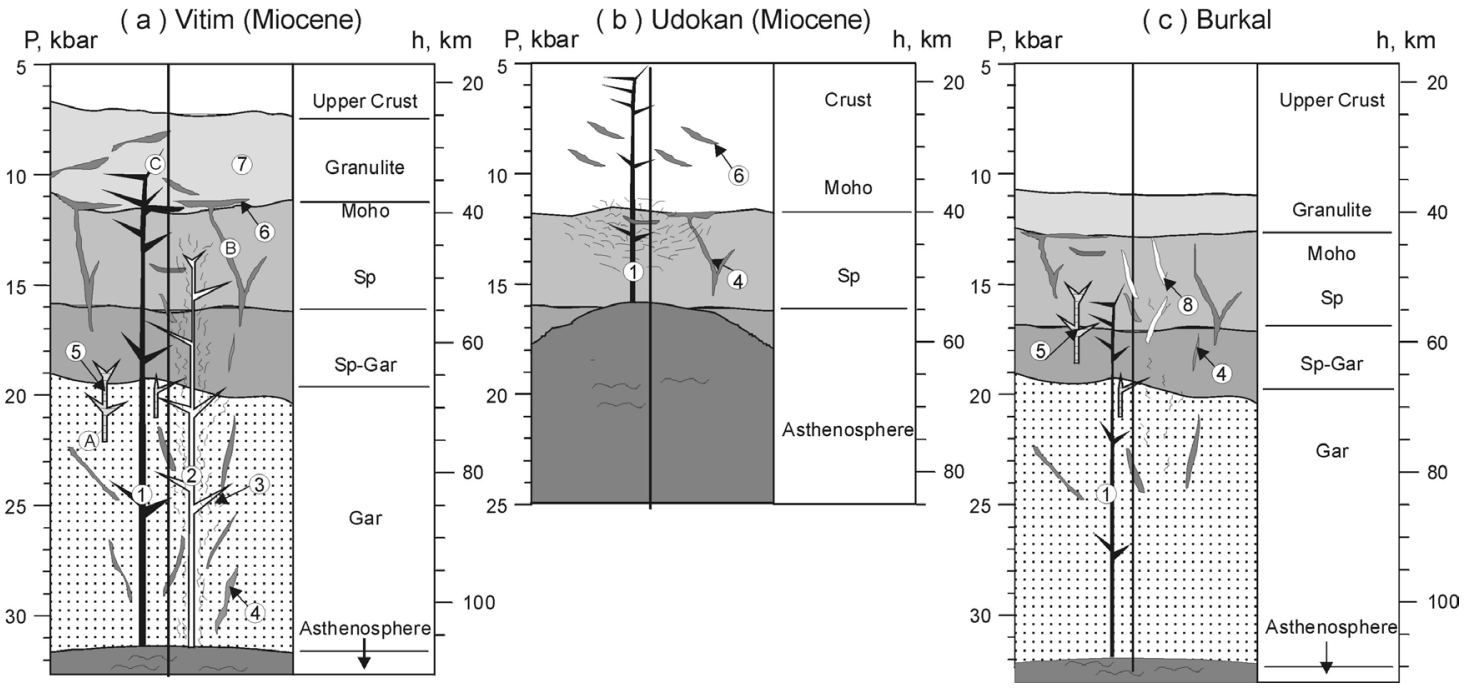

Figure 3. Schematic representation of the end member mantle columns beneath the volcanic field in the Baikal region as deciphered from peridotite and pyroxenite xenoliths. (a) Lithosphere slope: Vitim volcanic field, Miocene picrobasalts. Numbered veining systems: (1) megacryst and pyroxenite assemblages of Groups II; (2) volatile-bearing veins of Group II with (3) related metasomatic zone in the wall-rocks; (4) Older Cr-diopside-pyroxenites of Group I; (5) Al-rich clinopyroxenite veins; (6-7) - lower crustal and uppermost mantle Sp pyroxenites (6) and Gt granulites (7). Note presumed genetic correlations between Cr-diopside pyroxenite and Al-rich clinopyroxenite (A), between Cr-diopside pyroxenite and Al-augite Sp-websterites, and between the most fractionated megacrysts and Gt-bearing gabbro (C). Lithosphere-asthenosphere boundary in the figures was constructed using geophysical (Zorin et al., 1989) and geochemical data (Litasov and Taniguchi, 2002). Similar structure is characteristic for Bartoy and Taryat areas. (b) Thin axial lithosphere: Udokan volcanic field, Northern volcanoes. Note strong anhydrous metasomatic modification of the uppermost mantle resulted in formation of abundant feldspar-bearing melt pockets in the peridotite xenoliths. The mantle columns beneath Azas, Oka, Hamar-Daban, Vitim (Pliocene) and Udokan (Pliocene) have similar structure, but with thicker lithosphere (up to 60-80 km). (c) Thick aside lithosphere: Burkal volcanic field. Note restricted metasomatic modification and absence of hydrous phases. Pyroxenite series of the crust-mantle boundary are also rare. (8) Dunite veins, surrounded by depleted harzburgite.

located on the lithosphere slopes and contain rare xenoliths of garnet peridotite (from the depth greater than 50-55 km). However, differences between these off-axial fields are very strong, due to possible extension of rift structures from Tunka basins to Sayan and East Tuva. T-P estimations for Gt and Sp lherzolites from Pliocene-Pleistocene basalts suggest essential heating of lithosphere, evidenced from Bartoy and Sayan geotherms (Fig.2) and similarity of temperatures for spinel peridotites in these localities and Hamar-Daban area. We have detected that petrologic crust-mantle boundary is different from the seismic Moho according to possible location of lowtemperature spinel peridotite xenoliths near $32-35 \mathrm{~km}$ depth. Crust-mantle transition zone in the South Baikal area is interpreted as being to be the complex pyroxenite-peridotite section located between 32 and $45-50 \mathrm{~km}$.

\section{BARTOY}

Isotopic study of primary peridotite substrate suggests strong heterogeneity of the mantle beneath the Bartoy volcanic field due to series of depletion/enrichment events (Ionov et al., 1992). Most samples have MORB to OIB-like isotopic characteristics indicating enrichment and re-equilibration of primary substrate about 300-400 Ma ago based on model age estimations. Magmatic vein system reconstructed beneath the Bartoy is very similar to that for the Vitim field (Miocene). Differences for the Bartoy field include: (1) shallower position of lithosphere/asthenosphere boundary explaining an absence of garnet-bearing peridotite among the Bartoy xenoliths; (2) expansion of Amp-Phl metasomatism; (3) formation of amphibole megacrysts; (4) obvious genetic kinship between metasomatic Amp$\mathrm{Phl}$ veins and clinopyroxene megacrysts, including related pyroxenites.

\section{BURKAL}

Mantle xenoliths from the Burkal River melanephelinite represent mantle domain aside of the Rift system, and coincide with domal uplift of the Khentey mountains. Abundant dunite xenoliths and dunite veins in lherzolite suggest depleted mantle domain (Fig.3c). Even some 
Gt-bearing peridotites have depleted composition. Hydrous metasomatic modification was not detected, however shallow mantle feldspatic metasomatism similar with those in the Hamar-Daban and Udokan was found. Pyroxenite xenoliths of the both $\mathrm{Cr}$-diopside and Al-augite series are rare. T-P estimations for Gt and Sp lherzolites provide geotherm similar with that from xenoliths in the Vitim Pliocene basanites (Fig.2).

\section{UDOKAN}

Uppermost mantle beneath Northern part of Udokan volcanic field has extremely depleted composition (Fig.3b), whereas mantle beneath central part are more fertile with subordinate depleted harzburgite and dunite xenoliths. The variations in modal and major element composition in the Udokan peridotites most likely result from different degrees of partial melting and melt extraction from the fertile mantle source which is strongly suggested by the whole rock correlation of $\mathrm{MgO}$ with $\mathrm{Al}, \mathrm{Ca}$ etc. However, study of trace element chemistry of Cpx suggests that LREE-depleted trace element patterns characterizing simple partial melting is absent. Cpx from depleted Udokan peridotites shows a range of trace element enrichment due to an interaction with mantle fluids or small melt fractions.

\section{REFERENCES}

Ashchepkov, I.V., 1991. Deep-seated xenoliths of the Baikal rift. Nauka, Novosibirsk (in Russian).

Brey, G.P., Köhler, T., 1990. Geothermobarometry in fourphase lherzolites II. New thermobarometers, and practical assessment of existing thermobarometers. Jour. Petrol. 31, 1313-1336.

Delvaux, D., Moeys, R., Stapel, G., Melnikov, A., Ermikov, V., 1995. Paleostress reconstructions and geodynamics of the Baikal region, Central Asia, Part I. Palaeozoic and Mesozoic pre-rifting evolution. Tectonophys. 252, 61-101.

Herzberg, C.T., 1978. Pyroxene geothermometry and geobarometry: experimental and thermodynamic evaluation of some subsolidus phase relations involving pyroxenes in the system $\mathrm{CaO}-\mathrm{MgO}-\mathrm{Al}_{2} \mathrm{O}_{3}$ $\mathrm{SiO}_{2}$. Geochim. Cosmochim. Acta 42, 945-957.

Ionov D.A., Kramm, U., Stosch, H.-G., 1992. Evolution of the upper mantle beneath southern Baikal rift zone: an Sr$\mathrm{Nd}$ isotope study of xenoliths from the Bartoy volcanoes. Contrib. Mineral. Petrol., 111: 235-247.

Ionov D.A., Ashchepkov, I.V., Stosch, H.-G., Witt-Eickschen, G., Seck, H.A., 1993. Garnet peridotite xenolith from the Vitim volcanic field, Baikal region: the nature of the garnet-spinel peridotite transition zone in the continental mantle. Jour. Petrol. 34, 1141-1175.

Ionov D.A., O'Reilly, S.Y., Ashchepkov, I.V., 1995. Feldspar-bearing lherzolite xenoliths in alkaline basalts from Hamar-Daban, southern Baikal region, Russia. Contrib. Mineral. Petrol. 122, 174-190.
Ionov D.A., O'Reilly, S.Y., Griffin, W.L., 1998. A geotherm and lithospheric section for Central Mongolia (Tariat region). In: Flower, M.F.J. (Ed.), Mantle dynamics and plate interactions in East Asia. AGU, Washington, Geodyn. series, 27, pp.127-153.

Kiselev, A.I. Popov, A.M., 1992. Asthenospheric diapir beneath the Baikal rift: petrological constraints. Tectonophys. 208, 287-295.

Litasov K.D., Taniguchi, H., 2002. Mantle evolution beneath the Baikal rift. CNEAS Monograph Series, v.5. Tohoku Univ., Sendai.

Litasov, K.D., Foley, S.F., Litasov, Y.D., 2000a. Magmatic modification and metasomatism of the subcontinental mantle beneath the Vitim volcanic field (East Siberia): evidence from trace element data on pyroxenite and peridotite xenoliths from Miocene picrobasalt. Lithos $54,83-114$.

Litasov, K.D., Litasov, Y.D., Mekhonoshin, A.S., Malkovets, V.G., 2000b. Geochemistry of clinopyroxenes and petrogenesis of mantle xenoliths from Pliocene basanites of the Dzhilinda River (Vitim volcanic field). Russ. Geol. Geophys. 41, 1555-1572.

Logatchev, N.A., Zorin, Y.A., 1992. Baikal rift system: structure and geodynamics. Tectonophys. 208, 273286.

Nickel, K.G., Green, D.H., 1985. Empirical geothermobarometry for garnet peridotites and implications for the nature of the lithosphere, kimberlites and diamonds. Earth Planet. Sci. Lett. 73, 158-170.

O'Neill, H.St.C., 1981. The transition between spinel lherzolite and garnet lherzolite, and its use as geobarometer. Contrib. Mineral. Petrol. 77, 185-194.

O'Reilly, S.Y., Griffin, W.L., 1985. A xenolith-derived geotherm for Southeastern Australia and its geophysical implications. Tectonophys. 111, 41-63.

Rasskazov, S.V., 1994. Magmatism related to the Eastern Siberia rift system and the geodynamics. Bull. Centres Rech. Explor.-Prod. Elf Aquitaine 18 (2), 437-452.

Wells, P.R.A., 1977. Pyroxene thermometry in simple and complex systems. Contr. Miner. Petrol. 62, 129-139.

Windley, B.F., Allen, M.A., 1993. Mongolian plateau: Evidence for a late Cenozoic mantle plume under central Asia. Geology 21, 295-298.

Zonenshain, L.P. and Savostin, L.A., 1981. Geodynamics of the Baikal Rift Zone and plate tectonics of Asia. Tectonophys. 76, 1-45.

Zorin, Y.A., Kozhevnikov, V.M., Novoselova, M.R., Turutanov, E.H., 1989. Thickness of the lithosphere beneath the Baikal rift zone and adjacent regions. Tectonophys. 168, 327-337.

Contact: KD Litasov, Inst. Mineral. Petrol. Econ. Geol., Tohoku Univ., Sendai, 980-8578, Japan, E-mail:

klitasov@ganko.tohoku.ac.jp 